\title{
Balancing Sustainability Transitions through State-Led Participatory Processes: The Case of the Dutch North Sea Agreement
}

\author{
Susan de Koning (D), Nathalie Steins *(D) and Luc van Hoof (D)
}

check for updates

Citation: de Koning, S.; Steins, N.; van Hoof, L. Balancing Sustainability Transitions through State-Led Participatory Processes: The Case of the Dutch North Sea Agreement. Sustainability 2021, 13, 2297. https:// doi.org/10.3390/su13042297

Academic Editor: Just Bayle-Sempere

Received: 4 January 2021

Accepted: 16 February 2021

Published: 20 February 2021

Publisher's Note: MDPI stays neutral with regard to jurisdictional claims in published maps and institutional affiliations.

Copyright: (c) 2021 by the authors. Licensee MDPI, Basel, Switzerland. This article is an open access article distributed under the terms and conditions of the Creative Commons Attribution (CC BY) license (https:// creativecommons.org/licenses/by/ $4.0 /)$.
Wageningen Marine Research, Wageningen University \& Research, Haringkade 1, 1976CP Ijmuiden, The Netherlands; susan.dekoning@wur.nl (S.d.K.); luc.vanhoof@wur.nl (L.v.H.)

* Correspondence: nathalie.steins@wur.nl; Tel.: +31-317-480-900

\begin{abstract}
Following the Paris Agreement, investing in renewable energy production at sea is perceived as a promising development. In addition, food security challenges place increased focus on utilizing seas and oceans while biodiversity and ecosystem integrity must be safeguarded. In the North Sea, these three challenges are combined by the Dutch government in a deliberative governance agreement, involving key stakeholders, aimed at establishing a marine spatial allocation strategy. This paper outlines the development and first outcomes of this agreement. Using concepts of sustainability transitions and deliberative governance, we examined the role of the Dutch government in creating sustainability solutions through cross-sectoral participation processes. Based on our results, we argue that only the government can bring together parties that do not actively seek cooperation, like fisheries organizations and wind farm developers. This is in line with the government's role to ensure compliance with international and national agreements, while also representing local (national) stakes. By opening up a discussion between parties that in the past were competing for marine space, the Dutch government has managed to make progress in obtaining transition goals. One of these transitions is the transition of the governance system itself, moving towards a more egalitarian style of policy making.
\end{abstract}

Keywords: sustainability transitions; participatory processes; deliberative governance; North Sea; marine spatial planning

\section{Introduction}

Following the Paris Agreement [1], nation states must reduce their impact on global warming by reducing greenhouse gas emissions. A key aspect of this challenge is considered to be renewable energy production. The production of renewable energy at sea, particularly by offshore wind farms (OWFs), is seen as a promising development, with a higher average output than land-based wind farms and fewer threats to cherished landscapes. They also provide maritime employment opportunities for coastal communities [2]. Seas and oceans are also increasingly considered an underexploited resource in dealing with future global food security challenges, especially in relation to aquaculture production [3-5]. At the same time, this potential is constrained by international agreements and regulations aiming at safeguarding marine biodiversity and ecological productivity. Unlocking the potential for blue renewable energy and marine food production must adhere to (inter)national nature conservation policy frameworks. To be able to ensure environmental sustainability while producing enough renewable energy and healthy food to sustain our societies, new governance arrangements or instruments are needed.

In the Netherlands, an attempt is being made to deal with these different challenges in an integrated and coordinated manner. Marine policies are currently geared towards balancing nature conservation and economic activities [6], in line with European-wide practices of marine spatial planning (MSP) [7]. MSP is based on the idea that we should 
not manage our oceans in a sectoral manner, but instead allocate (scarce) marine space within ecological sustainable boundaries to different sectors in an integrated, transparent and participative manner [8,9]. Dutch MSP allows the government to prioritize nature over economic activities, when economic activities significantly impact nature conservation goals as established in national and European law [10].

Like many other marine areas around the world, the Dutch Exclusive Economic Zone (EEZ) is increasingly being used by a wide range of sectors for a wide range of purposes [11,12]. Intensified use by existing users and the arrival of new users may lead to use conflicts [13-16]. OWFs in particular are a game-changer. By 2030, current OWFs will be scaled up from 957 MW (2017) to 11.5 GW. In addition, in the period up to 2050, the cabinet will allocate new OFWs for a total of 20 to 40 GW [17]. North Sea fishers are especially concerned about this large scale development of OWFs as these areas are no longer accessible to fishers using active fishing gears, and combined with other spatial measures, will have socio-economic consequences for the fleet, supply chain and ancillary services [18].

At the same time, the Dutch government is seeking to increase marine food production through sustainable fisheries and mariculture development as part of a strive for futureproof and circular food production $[19,20]$. In addition, as articulated by Dutch nature and environmental organizations (ENGOs), there is a societal claim that a larger surface of the Dutch EEZ needs to be designated as marine protected area. This would impact both the fishing industry and OWF development, as OWFs may impact nature conservation goals [21]. As decisions regarding OWF area allocation and construction are, from a technical, economic and political perspective, not easy to reverse, an integrated approach, where nature conservation, energy production and seafood harvesting can co-exist, is necessary [14,22].

To tackle these different challenges, the Dutch government set out to develop an integrated approach to marine use. The basis for their approach was the development of the Dutch policy document "North Sea 2030 Strategy" [19]. During the stakeholder consultations leading up to this strategy, fishers actively started seeking media attention for the perceived spatial claims and resulting use conflicts between fisheries and OWF development, including well-attended public fishers' demonstrations in major cities $[23,24]$.

In response to stakeholder concerns in the media and MSP consultations, and to speed up the North Sea 2030 Strategy, the Dutch government changed its approach and set up a North Sea Dialogue (Noordzeeoverleg). Under the supervision of an independent chair, government representatives, the main economic users and nature conservation organizations were tasked to arrive at a North Sea Agreement (NSA), outlining a road map for the multi-use of the Dutch North Sea. In June 2020, the agreement, which delineates spatial allocations for additional nature conservation areas and OWFs and provides for a EUR 200 million Transition Fund, was formalized [25], albeit without the final support of the fishing sector. The implementation of the NSA will be overseen by the North Sea Dialogue. The NSA is part of a shift in Dutch nature policies from government-led policies towards policies that are developed together with private partners and civil society organizations [26], and a move towards more deliberative, participatory governance $[6,27,28]$.

In this paper, we examined the role of the Dutch government in creating sustainability solutions through cross-sectoral participation processes using a deliberative governance arrangement. We use the case of the Dutch North Sea Agreement to study a unique and innovative way of governing EEZs and restructuring existing MSP, which can serve as inspiration for other countries dealing with sustainability transitions with a strong spatial dimension. We assess the outcomes, focusing on how the transition towards a more sustainable society is fostered and stimulated through deliberative governance. Through this study, we show how a more egalitarian form of policy making can foster transitions and connect different sectors, even when not all parties can be kept onboard. 


\section{Theoretical Framework}

The transition aimed for in the NSA is multi-faceted. One facet is the transition towards a society based on renewable energy $[25,29]$. The second is the transition towards a more nature-inclusive society, protecting nature and developing sustainable forms of harvesting from nature [25]. This second transition is related to the third, in which food production becomes more sustainable and preferably 'circular', meaning that nutrient cycles are closed [20].

Transitions such as these often encompass technical and social dimensions; therefore, they are often referred to as socio-technical transitions [30]. Their analysis led to the development of the multi-level transition perspective (MLP), consisting of three levels. The first and lowest level niche developments start at the lowest level, the technological niche. The next level, the regime, incorporates all dimensions (socio-cultural, policy, user practices and markets, production networks, industry structures, science and technology) shaping and stabilizing the current dominant technologies and practices. The third level is the sociotechnical landscape, which includes all overarching global and local developments possibly influencing regimes [31]. An overview of the different levels is depicted in Figure 1.

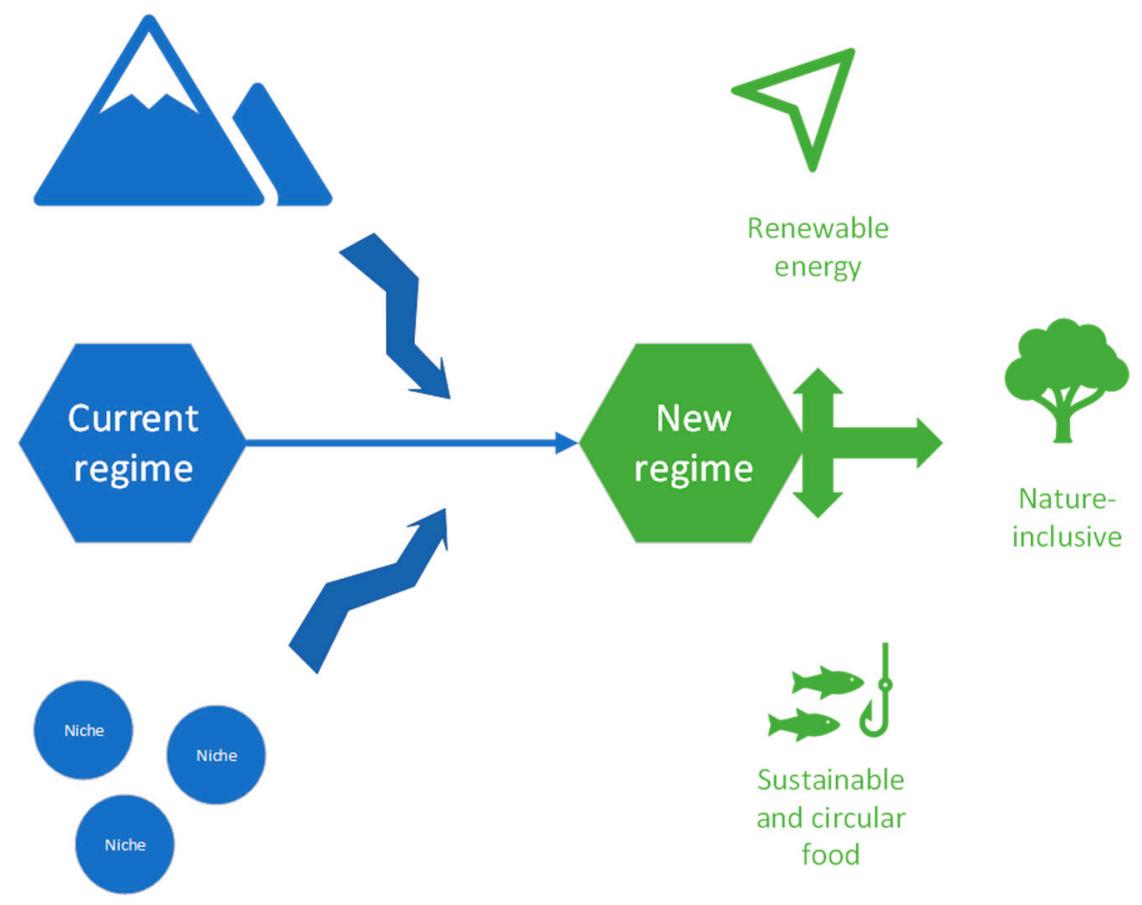

Figure 1. Using the multi-level perspective (niches, regime, landscape) to study the transition from the current regime(s) of the North Sea towards new regime(s).

Niches are generally small and unstable, with only a few actors. Regimes are complex, and more stable with more actors involved than niches. Socio-technological landscapes are literally 'the landscape' in which the regimes are placed and provide mainly background structures. Overall, when going from niches to landscapes, the complexity and stability of the system increases. This mechanism is also one of the reasons why transitions are uncommon [31]. Technological regimes are stable and thus not easily replaced. First, they have certain lock-in effects, that is, rules, routines, standards, policies, institutions and organizations aimed at, and tailored to, a specific technology. As a consequence, a transition has to change not only the specific technology, but all the dimensions related to the technological regime. Second, they contribute to the stability of the current sociotechnological regime by being path dependent. Path dependency is mainly articulated by actors investing in technologies [31]. For example, a company investing a large amount of money in conventional (based on fossil fuels) car engines, will not promote or support a transition towards electric driving [32]. 
While transition theory was developed mainly from the perspective of technological development, it can be applied more broadly [28,33], to solutions for problems that can be called 'wicked'. Wicked problems are characterized by scientific uncertainty and conflicting stakes and values, and include climate change, biodiversity loss, population growth and global food security. It is often difficult to delineate wicked problems, as they can be all-encompassing and ever-changing [34,35]. Therefore, some scholars argue that these problems can only be solved through radical system transformation or transitions [36].

In the solution of wicked problems, each transition can follow numerous transition pathways, which are often not clear beforehand [37]. They can be affected by governments developing policies influencing the direction, scale and speed through transition management, but transitions are too complex to be managed entirely [38]. Thus, so-called transition management (attempts to steer transitions in a certain way) has many forms. The most participatory is the egalitarian approach, focusing on the transition process itself rather than on the outcomes of the transitions [39]. If inclusiveness is a goal within the transition management approach, participatory processes are key [40]. Other approaches where processes are less central are, for example, the fatalistic approach, in which no pro-active action is taken, or the hierarchic approach, where a dominant group of actors takes the lead in steering the transition, or the individualist approach, based on the idea that individuals need the right conditions to contribute to transitions, and should therefore be stimulated through, for instance, market incentives [39].

Egalitarian forms of transition management can be constructed in a variety of ways. We hypothesize that the NSA is an attempt at egalitarian transition management through deliberative governance. Deliberative governance is a result of public deliberation within a governance arrangement [6]. Public deliberation is defined as "a combination of careful problem analysis and an egalitarian process in which participants have adequate speaking opportunities and engage in attentive listening or dialogue that bridges divergent ways of speaking and knowing" [41] (p. 398). Within deliberative governance, coalitions of governmental and non-governmental actors aim to solve a problem with shared urgency [42,43].

As traditional governmental policies are probably not apt for bringing about transitions [30], deliberative governance might be a solution for governments trying to stimulate and steer transitions. Since dominant institutions and social practices need to change, in order to be able to change the regime, deliberative governance can also be a co-evolutionary process, e.g., chaotic and non-linear [44]. Within these complex processes, the agency of the government as a single actor might be insufficient [28]. Therefore, we hypothesize that in the multi-level governance of Dutch policy making (between transnational, national, regional and local levels), in which power is shared among actors at multiple levels and on multiple scales [45], transitions can only occur when change is achieved on multiple levels involving multiple actors. This implies that the structural change of institutions and social practices requires an interplay between governance levels and different actors [28], making actor involvement in transition management and governance not only helpful, but a necessity.

\section{Material and Methods}

In this study, we used policy documents and input from workshops and previous research to conduct a policy analysis of the North Sea Agreement. We studied the policy documents available regarding the North Sea Dialogue, the North Sea Agreement and the process leading up to the North Sea Agreement. Furthermore, we examined media articles with regard to the North Sea Agreement, including the most common Dutch newspapers and specific media such as the independent fisheries newspaper and newsletters and publications from Dutch fisheries organizations. These documents were evaluated using transition theory and theories on multi-level and deliberative governance, as described in the previous section. Furthermore, the analysis builds on other research on the North Sea and marine governance performed by the authors (such as [18] and [21]) and discussions and workshops with representatives from the fishing industry, government, wind develop- 
ers and nature organizations. All policy documents which were used for our analysis can be found in the reference list.

\section{Study Area}

The Netherlands is a coastal nation, located on the shores of the North Sea. The North Sea is a shallow sea, surrounded by Great Britain, Norway, Denmark, Germany, the Netherlands and Belgium. It is known for being one of the busiest seas of the world [13]. The Dutch EEZ has a surface area of approximately $57,000 \mathrm{~km}^{2}$, which is 1.5 times the land surface of the Netherlands [11]. Important economic sectors operating in Dutch waters are fisheries, oil- and gas exploitation, sand and mineral extraction, shipping and since the 2006 the offshore wind energy industry. The Dutch North Sea fleet consists around 300 vessels, of which most vessels fish for flatfish species such as sole (Solea solea) and plaice (Pleuronectes platessa) [20]. Flatfish is caught using a pulse or beam trawl with tickler chains. Following EU regulations, pulse fishing must be terminated by June 2021 [46]. Beam trawling is known for its profound impact on the seafloor and the high amount of fuel needed [20]. In addition to the pulse ban, Brexit impacts Dutch demersal fisheries as 13\% of the Dutch sole quota will be transferred to the United Kingdom [47,48]. Oil-and gas exploitation takes place at 160 platforms, while sand and mineral extraction is performed at around $60-90 \mathrm{~km}^{2}$ per 5 years [11]. An area of $3600 \mathrm{~km}^{2}$ of the Dutch EEZ is designated as shipping area, supporting around 260,000 shipping movements per year. Offshore wind energy is expected to increase to a surface of $1100 \mathrm{~km}^{2}$. Other, non-commercial designated areas are nature areas and military areas [11]. Nature is protected through Natura 2000 areas $\left(11,374 \mathrm{~km}^{2}\right)$ which fall under the European Bird and Habitat Directives [11]. The area designated for military practice is $4200 \mathrm{~km}^{2}$ [11]. Figure 2 shows a map depicting the MSP of the North Sea as was planned for 2021.

Marine policy is primarily the responsibility of four different ministries [49]. The Ministry of Agriculture, Nature and Food Quality (Ministry of LNV) is responsible for fisheries, aquaculture and nature. The Ministry of Economic Affairs and Climate Policy (Ministry of EZK) is responsible for affairs with regard to (sustainable) energy. The Ministry of Infrastructure and Water Management (Ministry of $I \& W$ ) is responsible for maritime affairs. The Ministry of the Interior and Kingdom Relations (Ministry of BZK) is responsible for spatial planning [49]. Important European regulations applying to the Dutch EEZ are the aforementioned Bird and Habitat Directives, the Marine Strategy Framework Directive, the Water Framework Directive and the currently developed European Climate Law. For nature at the North Sea, the OSPAR convention (The Convention for the Protection of the Marine Environment of the North-East Atlantic) also applies, which is a regional seas convention [45]. 


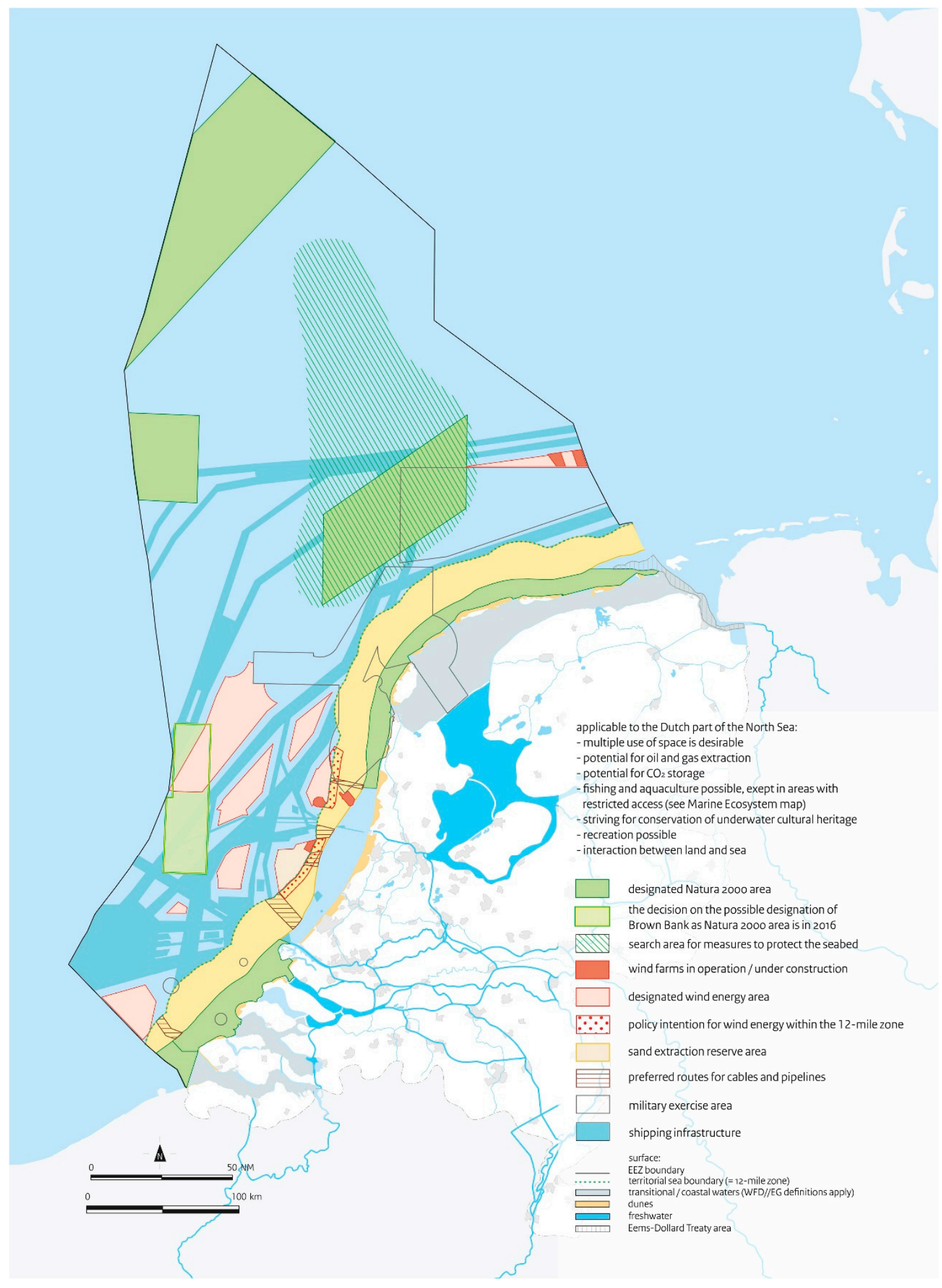

Figure 2. Marine spatial plan 2016-2021 [11].

\section{Results}

The Dutch government, nature organizations, the fishery sector and wind farm developers jointly developed an agreement on how to further develop policies which can ensure the protection of nature, a future for fisheries and the sufficient supply of renewable energy to reach the targets of the Dutch Climate Agreement [50]. The three main pillars of this North Sea Agreement (NSA; Noordzeeakkoord) look towards a transition in the 
production of energy, a transition towards restoration and the better protection of nature, as well as a transition towards sustainable fisheries and other forms of sustainable food production at sea. To facilitate its implementation, the NSA also includes a Transition Fund. The NSA will form the basis of the Strategic Agenda for the North Sea 2030 and the Program North Sea 2022-2027; hence, the NSA forms the basis for the future of the spatial planning of the Dutch part of the North Sea.

\subsection{Actions and Developments Leading Up to the Agreement}

The Dutch government is facing three challenges. First, it needs to implement the Paris agreement. Second, it needs to adhere to national and European laws, including those that require more areas to be designated as marine protected areas (MPAs), in some cases even as no-take zones with no fisheries allowed. Third, it also aims at circularity in the domain of food production [20], by reducing $\mathrm{CO}_{2}$ emissions, limiting the amount of bycatch in fisheries, using bycatch for other purposes and/or combining wind farms with shellfish, crustaceans and seaweed production [20]. To meet these combined challenges, the government developed the North Sea 2030 Strategy [18], including several consultation meetings with stakeholders. In this process, stakeholders from all interest groups raised concerns that OWF development was favored over other interests. Environmental nongovernmental organizations (ENGOs) demanded better and more marine protected areas, while the few fishing industry representatives present pointed out that none of the spatial allocation maps displayed any fishing activity.

As a result of the expansion of OWF locations and MPAs as part of the North Sea 2030 Strategy, the Dutch demersal fleet would lose access to important fishing grounds resulting in a significant socio-economic impact on the fishing communities. Fishers, who feel alienated from their territory and fear that OWF expansion will have significant ecosystem effects [21], sought media attention leading to questions in parliament. It became clear to the government that their traditional consultation approach was no longer sufficient to steer away from deadlock. This pushed the government towards the NSA process.

\subsection{Stakeholders in the NSA}

The North Sea Agreement is the outcome of the so-called North Sea Dialogue (Noordzeeoverleg). The Dialogue was tasked with balancing energy production, nature and food production and providing concrete spatial allocation to activities [25,50]. This dialogue is guided by Mr. Jacques Wallage, a former Dutch State Secretary. Hence, the dialogue is not state-led, but led by an independent chairman and facilitated by the independent Consultation Body for the Physical Living Environment (OFL). Table 1 presents an overview of its participants.

Table 1. Participants related to energy, nature and food in the North Sea Dialogue (in alphabetical order by sector).

\begin{tabular}{|c|c|c|c|c|}
\hline Sector & Organization & Description & $\begin{array}{l}\text { Signed the Negotiators' } \\
\text { Agreement of the NSA, } \\
5 \text { February } 2020 \text { [51] }\end{array}$ & $\begin{array}{l}\text { Signed the Final NSA, } \\
19 \text { June } 2020[25]\end{array}$ \\
\hline \multirow[b]{3}{*}{ Energy } & $\begin{array}{l}\text { Dutch Oil and Gas Exploration and } \\
\text { Production Association (NOGEPA) }\end{array}$ & $\begin{array}{l}\text { Represents all Dutch companies that } \\
\text { are allowed to search for oil and exploit } \\
\text { oil resources in the Dutch North Sea. }\end{array}$ & Yes & Yes \\
\hline & $\begin{array}{l}\text { Dutch Wind Energy Association } \\
\text { (NWEA) }\end{array}$ & Represents Dutch wind industry & Yes & Yes \\
\hline & $\begin{array}{l}\text { Energy Management The } \\
\text { Netherlands (EBN) }\end{array}$ & $\begin{array}{l}\text { State-owned organization which, } \\
\text { amongst other activities, facilitates } \\
\text { innovation in the Dutch energy sector. } \\
\text { Dutch-German company providing } \\
\text { power transmission services, system } \\
\text { services and facilitating the energy } \\
\text { market. TenneT is the designated grid } \\
\text { operator under the Dutch Energy Law } \\
\text { (Energiewet) and the German Energy } \\
\text { Sector Law (Energiewirtschaftsgesetz). }\end{array}$ & Yes & Yes \\
\hline
\end{tabular}


Table 1. Cont

\begin{tabular}{|c|c|c|c|c|}
\hline Sector & Organization & Description & $\begin{array}{l}\text { Signed the Negotiators' } \\
\text { Agreement of the NSA, } \\
5 \text { February } 2020 \text { [51] }\end{array}$ & $\begin{array}{l}\text { Signed the Final NSA, } \\
19 \text { June } 2020 \text { [25] }\end{array}$ \\
\hline Fishing industry & $\begin{array}{l}\text { Dutch Fisheries Association } \\
\text { (Vissersbond) }\end{array}$ & $\begin{array}{c}\text { National organization based on } \\
\text { individual fishers' membership. For } \\
\text { marine fisheries, representing } \\
\text { approximately } 25 \% \text { of the Dutch North } \\
\text { Sea demersal quota holders and } \\
\text { majority of brown shrimp license } \\
\text { holders. } \\
\text { Association of } 6 \text { Producers' } \\
\text { Organizations (POs) in the flatfish and } \\
\text { shrimp fisheries (no individual fisher's } \\
\text { membership). Represents } \\
\text { approximately 75\% of the Dutch } \\
\text { demersal quota and a minority of } \\
\text { brown shrimp license holders. } \\
\text { In the North Sea Dialogue, in addition } \\
\text { to representing its own } 6 \text { members, } \\
\text { POs acted as spokespersons on behalf } \\
\text { of } 4 \text { other separate fisheries } \\
\text { organizations, including the pelagic } \\
\text { industry and small-scale fisheries. }\end{array}$ & Yes & $\begin{array}{l}\text { Unable, because } \\
\text { Vissersbond and one of } \\
\text { VisNed's own PO } \\
\text { members refused to sign. }\end{array}$ \\
\hline \multirow{4}{*}{ Nature conservation } & Dutch Birdlife International & \multirow{4}{*}{$\begin{array}{l}\text { An organization aimed at restoring } \\
\text { biodiversity and the transition to a } \\
\text { climate neutral society. }\end{array}$} & Yes & Yes \\
\hline & Nature \& Environment Foundation & & Yes & Yes \\
\hline & North Sea Foundation & & Yes & Yes \\
\hline & $\begin{array}{l}\text { World Wide Fund for Nature } \\
\text { Netherlands (WWF-NL) }\end{array}$ & & Yes & Yes \\
\hline \multirow{3}{*}{$\begin{array}{l}\text { National } \\
\text { government }\end{array}$} & $\begin{array}{l}\text { Ministry of Agriculture, Nature and } \\
\text { Food Quality (Ministry of LNV) }\end{array}$ & & Yes & Yes \\
\hline & $\begin{array}{l}\text { Ministry of Economic Affairs and } \\
\text { Climate (Ministry of EZK) }\end{array}$ & & Yes & Yes \\
\hline & $\begin{array}{l}\text { Ministry of Water and Infrastructure } \\
\text { (Ministry of I\&W) }\end{array}$ & & Yes & Yes \\
\hline
\end{tabular}

\subsection{Deliberative Process}

As described in the previous paragraph, the process of developing the NSA was chaired and facilitated by the OFL. The OFL proposed a list of stakeholders to be included, which apart for the participants described in Table 1 also included the Organization of Seaports (BOZ), the Port of Rotterdam and the Royal Dutch Academy of Sciences (KNAW). To start off, six whole day meetings were organized, followed by five whole day sessions on specific topics. During the process, there were additional regular meetings. In the first half year, there were two meetings every three weeks. First, a meeting on a specific topic, in which scientists also took part, followed by a plenary session focused on the decision-making process. Different participants informed each other on their position and ideas through presentations, after which there was room for questions and discussions. Scientists were also invited in the specific meetings to present scientific insights with regard to the specific topic. After the first half year of deliberation, a two-day meeting with all participants took place. In addition to deliberation with the chosen stakeholders, there was also a consultation process for citizens and non-participating organizations. There was a two-week-long digital survey open to all citizens, followed by a physical meeting which was attended by 80 persons. The results of this consultation process were discussed within the North Sea Dialogue and the OFL provided the participants of the consultation process with an overview of if and how each point was included in the final agreement.

\subsection{What Is in It for Whom: Outcome of the Negotiations}

The negotiations took place along three axes (energy transition, nature transition and food transition) with four main actors, or stakeholder groups: the government, the energy sector, the ENGOs and the fisheries sector. The specific elements proposed in the agreement relating to each will be indicated by our analysis of the final text of the NSA [25].

An additional, an important part of the NSA is the government's ambition to enable the North Sea energy, nature and food transitions by creating a Transition Fund of EUR 200 
million [25]. A large part of this fund (EUR 120 million) was reserved for the restructuring of the Dutch demersal fishing fleet, as fishing grounds will have to be given up to realize the expansion of OWFs and MPAs. Fleet restructuring is to take place via decommissioning and innovation (vessels, gears).

\subsubsection{Energy}

While oil and gas producers at the North Sea will be able to continue their production, in the long term this activity will be phased out. Gas exploitation in Natura 2000 areas will continue under the strict terms already in place. The already existing plans with regard to OWFs for the 2023-2030 period in the NSA are treated as a fait accompli. Further investments in energy production at sea need to ensure that both the objectives of the climate agreement regarding energy production (in terms of TWh energy produced) are met, with a viable business case, and that consumers are protected against substantial energy cost increases.

The government wants the process of tendering for new OWFs to be transparent and wants to balance the different stakes concerned. In addition, it sees the multi-use of OWFs and other areas in the North Sea as the future standard. This will mean introducing 'area passports' which describe current users and potential forms of future multi-use in an area.

The energy sector as such gained little in the NSA but consolidated what was already achieved: ample space to develop new OWFs with support from the government. They gained a reduction in the burden of prolonged discussions with ENGOs and the fisheries sector. Within future OWFs, the sector needs to facilitate and enable multi-use, but will also be protected from related additional costs through the provision that the consumers energy bill should not increase due to this multi-use requirement.

\subsubsection{Nature}

Nature in the North Sea will become more protected, with an expansion of MPAs and areas where fisheries will become prohibited. OWFs will not be constructed in areas protected under European law and monitoring and research into the ecology of the North Sea and the impact of economic activities at sea will increase through additional funding.

OWFs will not be constructed in areas that are assigned as Natura 2000 or Marine Strategy Framework Directive (MSFD) areas. In addition, cumulative effects on fish, bird and marine mammal populations will be assessed, even when an OWF is not located in a designated nature conservation area. The precautionary principle will lead when deciding which activities are allowed to take place in MPAs. However, if activities have no significant impact on the nature conservation objectives in the specific area, activities can take place.

While currently $20 \%$ of the Dutch EEZ is already designated as an MPA [52], only a small part is currently closed to (bottom-trawling) fisheries. Under the NSA, additional MPAs will be created and by 2030, through a step-wise approach, $15 \%$ of the surface area of MPAs in the Dutch EEZ will be closed for bottom-trawl fisheries, including a $2.8 \%$ surface area with no fisheries at all. This was not as much as most ENGOs would have liked, as they aim for a 30\% surface coverage of MPAs across the world's oceans [53]. However, in view of the government's failure to adequately implement MPAs according to the ENGOs, they perceive these measures to be a significant step forward. Some ENGOs still fear the impact of the expansion of OWFs on life below and above water, and whether the compensation measures foreseen in the NSA will be enough to mitigate negative ecosystem effects.

Because of the existence of many knowledge gaps regarding the North Sea ecosystem and the possible impacts of the envisaged transitions, monitoring and research at the North Sea will be intensified. Extra funds for this monitoring and research will become available through the Transition Fund. Furthermore, through the NSA, the Dutch government is committed to publish a biannual report 'The State of the North Sea', detailing the environmental status of the North Sea. 


\subsubsection{Seafood}

Whereas in the NSA the agreements on the energy transition and nature transition are quite detailed in aim and scope [25] (p.11), the food transition is differently framed: the food transition at sea is presented as a strive to achieve a profitable and sustainable fishery that fits in with the new situation at the North Sea in terms of the fleet's characteristics and size. This will require a reorientation, and ultimately, a restructuring of the fleet. A food transition is not only an ecological necessity and a (business) economic reality, but also a social requirement: the people who work in the fishery, both at sea and on land, urgently need a clear perspective on the process of radical change. In addition, as the NSA notes, there is interest in developing alternative ways of production at sea (mariculture) requiring marine space. Concerning the allocation of fishing grounds, in total, $13.7 \%$ of the Dutch part of the North Sea will be closed for bottom trawling, and $2.8 \%$ closed to all types of fisheries by 2030, as part of the enhancement of MPAs. The measures for the closure of $13.7 \%$ of bottom-trawling will be effected once the financial means for the restructuring of the fishing fleet from the Transition Fund have been made available. Current OWFs in the southern part of the North Sea will remain closed for bottom trawling. However, it will be explored whether or not important areas for sole fisheries in the southern part of the North Sea can be excluded from OWF expansion and OWFs can be developed in more northerly parts instead.

The NSA also lays down that the government will seek to terminate fisheries restrictions in the Dutch part of the Plaice Box, except for the area called Borkumse Stenen. The Plaice Box has, under EU regulations, been closed for fishing to vessels with an engine capacity over $221 \mathrm{~kW}$ since 1989. The objective of the closure has, however, never been reached [54]. Lifting fisheries restrictions in the Plaice Box is politically complicated as the Plaice Box is an internationally closed area between the Netherlands, Germany and Denmark, laid down in EU regulations. Changes to this closed area will have to be negotiated at the European level, and while former evaluations of the Plaice Box commissioned by the EU found that the Plaice Box had little or no effect, since to date any attempts to adapt the management measures have failed [54].

Fixed fishing gear, like pots, and mariculture, will be allowed in all newly constructed OWFs. New OWFs will be equipped with anchoring possibilities, to stimulate passive fisheries and new economic activities. One could argue that the North Sea fisheries would experience some gain from the measures in the NSA. While the loss of fishing grounds and socio-economic consequences should certainly not be dismissed, the NSA recognizes the need to mitigate adverse effects. Thus, the larger part of the Transition Fund will be allocated to fleet restructuring to enable adaptation to fishing in a changed sea-scape. Funds from other sources will also be geared for innovation in the fisheries sector.

Regardless, after the consultation phase, in which stakeholders were able to consult their constituency before signing the agreement, the fishing industry did not sign [24]. A part of the industry felt that the NSA failed to provide enough perspective for the future generations of fishers $[55,56]$. This refusal did not affect the Transition Fund, which will still be used for the restructuring of the fleet and for innovation. This is surprising, as the government warned the fisheries sector during the consultation phase of the Negotiators' Agreement that 'no signing means neither funding nor a position at the Dialogue table' $[57,58]$. To understand the impact of the decision from the industry to withdraw from the agreement and the government's decision to continue with the Transition Funds on the implementation and governance of the NSA, there is a need for further in depth-analysis during the implementation phase.

\section{Discussion}

\subsection{Fostering Transitions}

The Dutch government seeks to balance multiple sustainability challenges. These challenges are embedded in a multi-level governance setting [59-62] where government operates in a nested negotiated, non-hierarchical exchange between institutions at the 
transnational, national, regional and local levels. The Dutch government is faced by obligations stemming from the Paris Agreement to reduce greenhouse gas emissions [1] In addition, in the context of the European Union institutions, the Dutch government has to address nature conservation requirements stemming from the Natura 2000 and MSFD regulations. Negotiated at the international and supra-national levels, they must implement these obligations at the local level. For the implementation at the local level, they developed the NSA. The challenge of reaching an NSA lay in building a deliberative compromise between the interests of several actors, given several transition challenges. Bringing all these stakeholder groups together allowed the government to, in a nested negotiated fashion, address the regime level of the required transition(s). Although in concrete terms the negotiations focused on the allocation of marine space, the dialogue focused on bringing together perspectives from all of the stakeholders' practices in order to re-shape the current dominant practices of marine spatial allocation.

The energy sector, although perhaps not gaining any new direct benefits, by reaching an agreement which embedded the already allocated 2020-2030 concessions, obtained a prolonged societal license to operate [63]. Through this process of dialogue, rather than through a technocratic process of marine space allocation, more support was mustered for the allocation of areas for future OWFs. This societal license to operate can aid in the process of establishing a new regime in terms of energy production, in which renewable energy becomes the norm and is widely accepted and embedded in policies and governance arrangements. Thus, the NSA seems to contribute to a transition in Dutch energy production.

With regard to the intended food transition, the Transition Fund enables the current food sector (fisheries) to become smaller but more sustainable at the same time [28]. Although part of the sector does not wish for a smaller fleet, fleet reduction will be inevitable due to the declining space for trawl fisheries due to OWF expansion. For alternatives to current food production, like seaweed or (shell) fish aquaculture, the outcomes do not seem to foster a transition. Officially, multi-use should become the norm at the North Sea. However, apart from the area passports, no concrete measures are foreseen to accomplish multi-use. OWF operators will not be obliged to facilitate multi-use, the only obligation they face is to explore possibilities for multi-use.

Nature conservation at sea also does not seem to go through a transition in the NSA. It establishes more protected areas, but this does not change the current regime. Most MPAs will remain open for (economic) activities, when activities can prove the absence of a negative impact on European nature conservation goals. Moreover, there are no concrete plans for other forms of nature conservation or nature restoration, although ENGOs are currently involved in small-scale pilots in-and outside of wind farms, actively seeking cooperation with the energy sector and in some cases even the fisheries sector (e.g., [64]). This 'niche' of restoring nature outside of MPAs is not fostered through the NSA agreements and is not included in official government policies.

\subsection{From Consultation to Deliberation}

The NSA process brought together actors that previously did not meet and consult on a regular basis. In fact, in the earlier process of allocating locations to marine activities, the Dutch government labelled as priorities quite a large number of activities (among which were oil and gas, OWF) to safeguard the access of those activities to the North Sea $[65,66]$, whereas others (mainly the fishing industry) were not allocated specific areas or locations. As a result, over time, these actors saw their area for operation considerably reduced [28,67]. In the policy process, in first instance, a rather traditional participatory set-up was employed. The North Sea 2030 Strategy was presented by a government in a consultation meeting process and stakeholders were invited to respond. This did not result in a broad support for the plans presented. In fact, these consultations were dominated by some parties and interests (cf. [68,69]) and stirred quite a lot of opposition [21]. 
Thus, to enable the desired combined transitions in energy, nature conservation and seafood, the decision making process itself had to go through a transition. As the agency of government as a single actor was insufficient to produce the required transition process(es) and fully control the transition processes [28,38], the government embarked on a co-evolutionary process [43]. In this, the government switched mode from a hierarchic approach [39], in which a dominant group of actors take the lead in steering the transition, especially the development of OWF, towards a more egalitarian participatory approach [39] where inclusiveness is a goal within the transition management approach [40]. The new deliberative governance process aimed at moving out of this deadlock resulting from intrinsic different and opposing visions of diverse stakeholder groups. The new process also implied that for the first time, fisheries received explicit recognition as a priority activity whose access to the North Sea should be ensured. Fisheries were literally put on the map of North Sea users, and not treated as an implicit given (or an activity that can simply move on to other areas following closures) as had previously been the case. Part of the fishing industry could not agree with the prioritization of OWF expansion in Dutch MSP, which was clear from the beginning of the dialogue. When taking OWF expansion as a starting point, however, the fishing industry did seem to benefit a lot from the process. The NSA resulted in the possibility for a company buy-out (decommissioning) and for the fishing companies that wanted to continue fishing the NSA provides funds to innovate and become more sustainable.

From mere consultation, the government developed a process in which they themselves were partners at the table, together with other stakeholders. Thereby, they are moving away from so-called tokenism in participation to a form in which participants have real power within the policy process [69]. As mentioned before, this shift from state-led participatory processes to deliberative governance can be seen in several government initiatives in other environmental domains in the Netherlands $[6,27,28]$. Among environmental policy scholars, there is a common idea that within participatory processes, governments often retain a dominant role, even if they are officially equal to other participants [70]. Therefore, it would be interesting to take a closer look into the process of decision-making within the North Sea Dialogue to be able to analyze the role of government in the NSA process.

\subsection{Towards a New Regime}

Another question that remains is whether the transition in governmental policy processes really contributes to improved sustainability in (marine) environmental policies. A literature review on the impact of participatory governance in the environmental domain shows that participatory processes can improve environmental policies, if the involved participants adhere to environmental goals as set by the initiator of the arrangement [71]. In practice, participatory processes often result in an exchange of interests, not in finding sustainability solutions in a collaborative fashion [71]. In the case of the NSA, the chair appealed to all parties to keep the health of the North Sea in mind during the process. For the seafood and nature sector this seems logical, as they are both dependent on a healthy North Sea for establishing their goals. Within the energy sector, this is not so obvious, as its goal (producing more renewable energy) is not dependent on or directly related to a healthy North Sea but rather related to global environmental goals with regard to climate change. Moreover, no further steps were taken to limit fossil fuel extractions in the North Sea, which would benefit both the energy and the nature transitions. The continued extraction from the North Sea is justified by stating that the Netherlands is still in need of fossil fuels, and that domestic extraction from smaller gas fields has a lower footprint than imported gas [25]. As such, one can doubt whether the NSA outcomes, which clearly benefit the energy sector and to a lesser extent the other sectors, really contribute to a healthier North Sea or whether the main achievements of the NSA are creating legitimacy for the energy transition and the transition of North Sea governance itself. 


\subsection{Topics for Further Research}

The current study is limited to a specific case and is conducted in a country with a long tradition of participative forms of governance. A comparative study of the best practices of government-steered deliberative governance for sustainability transitions could aid in a more general understanding of the potential of deliberative governance in addressing sustainability challenges in an integrative manner. Therefore, it would be interesting to compare case studies such as ours, as many countries are facing similar challenges in sustainability transitions. A review on MLP criticism also shows that there is a need for more research into horizontal policy integration and open and inclusive governance styles to foster sustainability transitions [72].

\section{Conclusions}

The North Sea Agreement relates to sharing the limited space available in the Dutch part of the North Sea among multiple uses. By opening up a discussion between parties that in the past were competing for marine space and a license to operate, the government managed to make progress in obtaining transition goals. One of these transitions is the transition of the governance system itself moving towards a more egalitarian deliberative and participatory means of policy making. Our results showed that deliberative governance can be a useful way of fostering transitions from a government perspective. In this case, three transitions were addressed through one agreement. Although this integrative and deliberative approach has many benefits, this case also shows that there can be trade-offs between different types of sustainability transitions (energy, nature, food) which cannot be entirely overcome. In this case, renewable energy development was not challenged, nor were the planned development areas open to discussion. However, when comparing the NSA to the previous MSP processes, nature organizations and the fishing industry did benefit from this novel governance approach. Whereas previously the government allocated areas in which OWFs would become the sole form of use, wind operators now have to deal explicitly with other users and interests, such as nature conservation and fisheries, in the design, construction and operation of OWFs. Thus, deliberative governance such as in the NSA can contribute to a level-playing field for all stakeholders in crosssectoral environmental policy making.

Author Contributions: Conceptualization, S.d.K. and L.v.H.; methodology, S.d.K. and L.v.H.; formal analysis, S.d.K. and L.v.H.; investigation, S.d.K., L.v.H. and N.S.; writing — original draft preparation, S.d.K.; writing - review and editing, S.d.K., L.v.H. and N.S.; Supervision, L.v.H. and N.S.; project administration, L.v.H.; funding acquisition, L.v.H. All authors have read and agreed to the published version of the manuscript.

Funding: The research was funded under the Knowledge Base program KB-1-1D-1 of Wageningen University and Research.

Institutional Review Board Statement: Not applicable.

Informed Consent Statement: Not applicable.

Data Availability Statement: No new data were created or analyzed in this study. Data sharing is not applicable to this article.

Acknowledgments: We would like to thank all stakeholders and colleagues from Wageningen Marine Research with whom we have discussed the development of the North Sea Agreement and who inspired us for writing this paper.

Conflicts of Interest: The authors declare no conflict of interest.

\section{References}

1. United Nations. Paris Agreement; United Nations: Paris, France, 2015.

2. European Commission. Report on the Blue Growth Strategy: Towards More Sustainable Growth and Jobs in the Blue Economy; European Commission: Brussels, Belgium, 2017; pp. 1-62.

3. Costello, C.; Cao, L.; Gelcich, S. The Future of Food from the Sea. Nature 2020, 588, 95-100. [CrossRef] [PubMed] 
4. Gentry, R.R.; Froehlich, H.E.; Grimm, D.; Kareiva, P.; Parke, M.; Rust, M.; Gaines, S.D.; Halpern, B.S. Mapping the Global Potential for Marine Aquaculture. Nat. Ecol. Evol. 2017, 1, 1317-1324. [CrossRef] [PubMed]

5. Lehahn, Y.; Ingle, K.N.; Golberg, A. Global Potential of Offshore and Shallow Waters Macroalgal Biorefineries to Provide for Food, Chemicals and Energy: Feasibility and Sustainability. Algal Res. 2016, 17, 150-160. [CrossRef]

6. De Koning, S.; Steins, N.A.; Toonen, H.M. Struggling over Shellfish: How Diverging Perceptions of Marine Nature Distort Deliberative Governance. Ocean. Coast. Manag. 2020, 198, 105384. [CrossRef]

7. Flannery, W.; Ellis, G.; Flannery, W.; Nursey-Bray, M.; van Tatenhove, J.P.M.; Kelly, C.; Coffen-Smout, S.; Fairgrieve, R.; Knol, M. Exploring the Winners and Losers of Marine Environmental Governance/Marine Spatial Planning: Cui Bono? /More than Fishy Business: Epistemology, Integration and Conflict in Marine Spatial Planning/Marine Spatial Planning: Power and Scaping/Surely Not All. Plan. Theory Pract. 2016, 17, 121-151. [CrossRef]

8. Claydon, J. Viewpoint Marine Spatial Planning: A New Opportunity for Planners. Town Plan. Rev. 2006, 77. [CrossRef]

9. Trouillet, B. Reinventing Marine Spatial Planning: A Critical Review of Initiatives Worldwide. J. Environ. Policy Plan. 2020, 22, 441-459. [CrossRef]

10. Floor, J.R.; Van Koppen, C.S.A.; Van Tatenhove, J.P.M. Uncertainties in the Assessment of "Significant Effect" on the Dutch Natura 2000 Wadden Sea Site-The Mussel Seed Fishery and Powerboat Race Controversies. Environ. Sci. Policy 2016, 55, 380-392. [CrossRef]

11. De Vrees, L. Adaptive Marine Spatial Planning in the Netherlands Sector of the North Sea. Mar. Policy 2019, 1, 1-10. [CrossRef]

12. Wright, G. Marine Governance in an Industrialised Ocean: A Case Study of the Emerging Marine Renewable Energy Industry. Mar. Policy 2015, 52, 77-84. [CrossRef]

13. Jentoft, S.; Knol, M. Marine Spatial Planning: Risk or Opportunity for Fisheries in the North Sea? Marit. Stud. 2014, 12. [CrossRef]

14. Schupp, M.F.; Bocci, M.; Depellegrin, D.; Kafas, A.; Kyriazi, Z.; Lukic, I.; Schultz-Zehden, A.; Krause, G.; Onyango, V.; Buck, B.H. Toward a Common Understanding of Ocean Multi-Use. Front. Mar. Sci. 2019, 6, 165. [CrossRef]

15. Steins, N.A.; Edwards, V.M. Platforms for Collective Action in Multiple-Use Common-Pool Resources. Agric. Hum. Values 1999, 16, 241-255. [CrossRef]

16. van Ginkel, R.; Steins, N. Multi-Use Conflicts in Inshore Waters. In Inshore Fisheries Management; Symes, D., Phillipson, J., Eds.; Springer: Dordrecht, The Netherlands, 2001; pp. 257-273. [CrossRef]

17. EZK. Kabinetsaanpak Klimaatbeleid; Brief van de Minister van Economische Zaken en Klimaat aan de voorzitter van de Tweede Kamer der Staten-Generaal: The Hague, The Netherlands, 4 December 2020.

18. Quirijns, F.J.; Steins, N.A.; Zaalmink, B.W.; Mol, A.; Kraan, M.; Strietman, W.J.; Molenaar, P. Duurzame Noordzee Kottervisserij in Ontwikkeling; Wageningen University \& Research: Wageningen, The Netherlands, 2019.

19. IDON. Flyer Noordzee 2030; Interdepartementaal Directeurenoverleg Noordzee: The Hague, The Netherlands, 2017.

20. LNV. Landbouw, Natuur en Voedsel: Waardevol en Verbonden; LNV: The Hague, The Netherlands, 2018 ; p. 21.

21. Steins, N.A.; Veraart, J.A.; Klostermann, J.; Poelman, M. Combining Offshore Wind Farms, Nature Conservation and Seafood: Lessons from a Dutch Community of Practice. Mar. Policy 2021, 126, 103471. [CrossRef]

22. Soma, K.; Burg, S.W.K.; Selnes, T.; Heide, C.M. Assessing Social Innovation across Offshore Sectors in the Dutch North Sea. Ocean. Coast. Manag. 2019, 167, 42-51. [CrossRef]

23. NOS. Boze Vissers Delen vis uit als Protest Tegen EU-Milieuregel. Available online: https://nos.nl/artikel/2128425-boze-vissersdelen-vis-uit-als-protest-tegen-eu-milieuregels.html (accessed on 5 October 2020).

24. Visserijnieuws. Vissers Leggen Eisen op Tafel. Available online: https://www.visserijnieuws.nl/nieuws/vissers-leggen-eisenop-tafel (accessed on 5 October 2020).

25. OFL. Het Akkoord Voor de Noordzee; Wageningen University \& Research: Wageningen, The Netherlands, 2020.

26. Arnouts, R.; van der Zouwen, M.; Arts, B. Analysing Governance Modes and Shifts-Governance Arrangements in Dutch Nature Policy. For. Policy Econ. 2012, 16, 43-50. [CrossRef]

27. Beunen, R.; de Vries, J.R. The Governance of Natura 2000 Sites: The Importance of Initial Choices in the Organisation of Planning Processes. J. Environ. Plan. Manag. 2011, 54, 1041-1059. [CrossRef]

28. Van Hoof, L.; Steins, N.A.; Smith, S.; Kraan, M. Change as a Permanent Condition: A History of Transition Processes in Dutch North Sea Fisheries. Mar. Policy 2020, 8, 104245. [CrossRef]

29. Solorio, I.; Jörgens, H. Contested Energy Transition? Europeanization and Authority Turns in EU Renewable Energy Policy. J. Eur. Integr. 2020, 42, 77-93. [CrossRef]

30. Grin, J. The Politics of Transition Governance. Conceptual Understanding and Implications for Transition Management. Int. J. Sustain. Dev. 2011, 14, 1-19.

31. Grin, J.; Rotmans, J.; Schot, J. Transitions to Sustainable Development: New Directions in the Study of Long Term Transformative Change; Routledge: Abingdon-on-Thames, UK, 2010.

32. Greenblatt, N.A. Self-Driving Cars and the Law. IEEE Spectr. 2016, 53, 46-51. [CrossRef]

33. Zwartkruis, J.V.; Berg, H.; Hof, A.F.; Kok, M.T.J. Agricultural Nature Conservation in the Netherlands: Three Lenses on Transition Pathways. Technol. Forecast. Soc. Chang. 2020, 151, 119235. [CrossRef]

34. Dentoni, D.; Bitzer, V. The Role(s) of Universities in Dealing with Global Wicked Problems through Multi-Stakeholder Initiatives. J. Clean. Prod. 2015, 106, 68-78. [CrossRef]

35. Jentoft, S.; Chuenpagdee, R. Fisheries and Coastal Governance as a Wicked Problem. Mar. Policy 2009, 33, 553-560. [CrossRef] 
36. McKee, A.; Holstead, K.; Sutherland, L.A.; Pinto-Correia, T.; Guimaraes, H. 'Shift Happens': Co-Constructing Transition Pathways towards the Regional Sustainability of Agriculture in Europe. In Proceedings of the 11th European International Farming Systems Association Symposium, Berlin, Germany, 1-4 April 2014.

37. Geels, F.W.; Schot, J. Typology of Sociotechnical Transition Pathways. Res. Policy 2007, 36, 399-417. [CrossRef]

38. Rotmans, J.; Kemp, R.; Van Asselt, M. More Evolution than Revolution. Foresight 2001, 3, 1-17. [CrossRef]

39. Tukker, A.; Butter, M. Governance of Sustainable Transitions: About the 4(0) Ways to Change the World. J. Clean. Prod. 2007, 15, 94-103. [CrossRef]

40. Rut, M.; Davies, A.R.; Ng, H. Participating in Food Waste Transitions: Exploring Surplus Food Redistribution in Singapore through the Ecologies of Participation Framework. J. Environ. Policy Plan. 2020, 1-14. [CrossRef]

41. Burkhalter, S.; Gastil, J.; Kelshaw, T. A Conceptual Definition and Theoretical Model of Public Deliberation in Small Face-to-Face Groups. Commun. Theory 2002, 12, 398-422. [CrossRef]

42. Benhabib, S. Democracy and Difference: Contesting the Boundaries of the Political; Princeton University Press: Princeton, NJ, USA, 1996.

43. Hendriks, C.M. Deliberative Governance in the Context of Power. Policy Soc. 2009, 28, 173-184. [CrossRef]

44. Beunen, R.; Van Assche, K.; Duineveld, M. Evolutionary Governance Theory; Springer International Publishing: Cham, Switzerland, 2015.

45. Piattoni, S. Multi-level Governance: A Historical and Conceptual Analysis. J. Eur. Integr. 2009, 31, 163-180. [CrossRef]

46. Kraan, M.; Groeneveld, R.; Pauwelussen, A.; Haasnoot, T.; Bush, S.R. Science, subsidies and the politics of the pulse trawl ban in the European Union. Mar. Policy 2020, 118, 103975. [CrossRef]

47. European Union \& United Kingdom. Agreement on the Withdrawal of the United Kingdom of Great Britain and Northern Ireland from the European Union and the European Atomic Energy Community 2019/C 384 I/01; European Union: Brussels, Belgium, 2019.

48. Visserijnieuws 2020. Brexit-Deal Kost Nederlandse Vissers Kapitalen. Available online: https://www.visserijnieuws.nl/nieuws/ brexit-deal-kost-nederlandse-vissers-kapitalen (accessed on 6 February 2021).

49. De Koning, S.; Trul, D. Kansen en Barrières voor Offshore Mosselkweek op de Noordzee en in de Voordelta: Een Studie naar de Percepties van de Sociaal-Economische Haalbaarheid, Ruimtelijke Inpasbaarheid en de Impact op Natuur van Offshore Mosselkweek (No. C102/20); Wageningen Marine Research: Wageningen, The Netherlands, 2020.

50. Ministerie van EZK. Klimaatakkoord; Ministerie van EZK: The Hague, The Netherlands, 2019; p. 250.

51. OFL. Onderhandelaarsakkoord Voor de Noordzee. Extra Mijlen Voor Een Gezonde Noordzee; OFL: The Hague, The Netherlands, 2020.

52. Matthijsen, J.; Dammers, E.; Elzenga, H. De Toekomst van de Noordzee. De Noordzee in 2030 En 2050: Een Scenariostudie; Wageningen University \& Research: Wageningen, The Netherlands, 2018; Volume 272.

53. Seas at Risk; Birdlife International; ClientEarth; Oceana; Surfrider Foundation; WWF. Blue Manifesto: The Roadmap to a Healthy Ocean in 2030; Seas at Risk: Brussels, Belgium, 2020.

54. Beare, D.; Rijnsdorp, A.D.; Blaesberg, M.; Damm, U.; Egekvist, J.; Fock, H.; Kloppmann, M.; Röckmann, C.; Schroeder, A.; Schulze, T.; et al. Evaluating the Effect of Fishery Closures: Lessons Learnt from the Plaice Box. J. Sea Res. 2013, 84, 49-60. [CrossRef]

55. Nederlandse Vissersbond. Vissector Stapt uit Overleg Noordzeeakkoord. Available online: https://www.vissersbond.nl/ persbericht-vissector-stapt-uit-overleg-noordzeeakkoord/ (accessed on 7 October 2020).

56. Nederlandse Vissersbond. Nederlandse Vissersbond Stemt Niet in Met de Huidige Tekst Voor een Noordzeeakkoord. Available online: https: / / www.vissersbond.nl/nederlandse-vissersbond-stemt-niet-in-met-de-huidige-tekst-voor-een-noordzeeakkoord/ (accessed on 7 October 2020).

57. Visserijnieuws. Hulp aan Visserijwereld op een Tweesprong. Available online: https://www.visserijnieuws.nl/nieuws/14847hulp-aan-visserijwereld-op-een-tweesprong (accessed on 20 October 2020).

58. Visserijnieuws. Stemming Uitgesteld: Zoektocht Naar Opening in Noordzeeakkoord; Visserijnieuws: Urk, The Netherlands, 2020.

59. Guy Peters, B.; Pierre, J. Developments in Intergovernmental Relations: Towards Multi-Level Governance. Policy Polit. 2001, 29, 131-135. [CrossRef]

60. Hooghe, L.; Marks, G. Unraveling the Central State, but How? Types of Multi-Level Governance. Am. Polit. Sci. Assoc. 2003, 97, 233-243.

61. Zürn, M. Global Governance as Multi-Level Governance. In Handbook on Multi-Level Governance; Enderlein, H., Wälti, S., Zürn, M., Eds.; Edward Elgar Publishing: Cheltenham, UK, 2010; pp. 80-99.

62. Bache, I.; Bartle, I.; Flinders, M. Multi-Level Governance. In Handbook on Theories of Governance; Ansell, C., Torfing, J., Eds.; Edward Elgar Publishing: Cheltenham, UK, 2016; pp. 486-498. [CrossRef]

63. Smits, C.C.A.; van Leeuwen, J.; van Tatenhove, J.P.M. Oil and Gas Development in Greenland: A Social License to Operate, Trust and Legitimacy in Environmental Governance. Resour. Policy 2017, 53, 109-116. [CrossRef]

64. WWF. Noordzeenatuur Herstellen. Available online: https://www.wwf.nl/wat-we-doen/resultaten/projecten/noordzeeherstellen (accessed on 21 November 2019).

65. Van Hoof, L.; Bolman, B.; Röckmann, C.; Kraan, M.; Jak, R.; Van De Wall, J.; Slijkerman, D.; Groenendijk, F.; Smith, S. Zee Op Zicht: Inzicht: Gepubliceerde Literatuur E Verslag Slotbijeenkomst; Wageningen University \& Research: Wageningen, The Netherlands, 2014 . 
66. Van Hoof, L.; Steenbergen, J.; Bolman, B.; Röckmann, C.; Kraan, M.; Piet, G.J.; Jak, J.; Van der Wal, J.T.; Pastoors, M.A.; Slijkerman, D.; et al. Zee Op Zicht: Inzicht Een Zoektocht Naar Een Integraal Afwegingskader Voor Het Gebruik van de Zee; Wageningen University \& Research: Wageningen, The Netherlands, 2014.

67. Productschap Vis. Nota Ruimte Voor Visserij. Vissen Op Een Postzegel; Productschap Vis: Rijswijk, The Netherlands, 2004.

68. Flannery, W.; Healy, N.; Luna, M. Exclusion and Non-Participation in Marine Spatial Planning. Mar. Policy 2018, 88, 32-40. [CrossRef]

69. Arnstein, S.R. A Ladder of Citizen Participation. J. Am. Plan. Assoc. 2019, 85, 24-34. [CrossRef]

70. Olvera-Garcia, J.; Neil, S. Examining How Collaborative Governance Facilitates the Implementation of Natural Resource Planning Policies: A Water Planning Policy Case from the Great Barrier Reef. Environ. Policy Gov. 2020, 30, 115-127. [CrossRef]

71. Newig, J.; Fritsch, O. Environmental Governance: Participatory, Multi-Level-And Effective? Environ. Policy Gov. 2009, 19, 197-214. [CrossRef]

72. Geels, F.W. Socio-technical transitions to sustainability: A review of criticisms and elaborations of the Multi-Level Perspective. Curr. Opin. Environ. Sustain. 2019, 39, 187-201. [CrossRef] 